\title{
Apolipoprotein E4 Measurement
}

National Cancer Institute

\section{Source}

National Cancer Institute. Apolipoprotein E4 Measurement. NCI Thesaurus. Code C92293.

The determination of the amount of apolipoprotein E4 present in a sample. 